\title{
Occult Hepatitis B Virus and Hepatitis B Genotypes among Renal Transplant Patients in Khartoum State, Sudan
}

\author{
Mohamed O Mustafa ${ }^{1 *}$, Khalid A Enan ${ }^{1}$, Isam M Elkhidir ${ }^{2}$ and Abdel Rahim M El Hussein ${ }^{1}$ \\ ${ }^{1}$ Department of Virology, Central Laboratory, Ministry of Higher Education and Scientific Research, Sudan \\ ${ }^{2}$ Department of Microbiology and Parasitology, Faculty of Medicine, University of Khartoum, Sudan
}

"Corresponding authors: Mohamed O Mustafa, Department of Virology, Central Laboratory, Khartoum, Ministry of Higher Education and Scientific Research, Sudan, Tel: +249916503948; +249-120799630; E-mail: king07_moha@yahoo.com

Received: 20 Nov, 2018 | Accepted: 18 Jan, 2019 | Published: 25 Jan, 2019

Citation: Mustafa MO, Enan KA, Elkhidir IM, El Hussein ARM (2019) Occult Hepatitis B Virus and Hepatitis B Genotypes among Renal Transplant Patients in Khartoum State, Sudan. J Emerg Dis Virol 5(1): dx.doi.org/10.16966/2473-1846.147

Copyright: (c) 2019 Mustafa MO, et al. This is an open-access article distributed under the terms of the Creative Commons Attribution License, which permits unrestricted use, distribution, and reproduction in any medium, provided the original author and source are credited.

\section{Abstract}

Background: Occult (Inapparent) Hepatitis B Virus Infection (OBI) distinguished by undetectable HBsAg and detectable anti-Hbc continues to be a great threat to blood safety. We examined the prevalence of $\mathrm{OBI}$ and $\mathrm{HBV}$ genotypes of $\mathrm{OBI}$ among renal transplant patients.

Methods: One hundred samples were collected from renal transplant patient from different centers in Khartoum State. The specimens were investigated for HBV Surface Antigen ( $\mathrm{HBsAg}$ ) and HBV core (HBc) antibodies using Immune Enzymatic Assay (ELISA), and HBV DNA using PCR and Real time PCR and for HBV genotypes using Multiplex Nested PCR.

Results: A total of 100 clinical samples were tested for HBsAg of which 97 samples (97\%) were negative for HBsAg by ELISA and thirty-seven samples (38.1\%) were positive for $\mathrm{HBc}$ antibodies. All of the 37 samples positive for $\mathrm{HBC}$ antibodies were negative for $\mathrm{HBV}$ DNA (0.0\%) using PCR; Real time PCR detected only 19(51.4\%) positive DNA samples; while different HBV genotypes (A,D, and E) and their co-infections thereof were detected in 24(64.9\%) samples using Multiplex Nested PCR. The percentage of anti-HBc positivity was higher (42\%) in males compared to females (33\%). Occult HBV prevalence was almost equal when using Multiplex Nested PCR being $65.2 \%$ and $64.3 \%$ in males and females respectively while it was higher in females $(57.1 \%)$ than in males (47.8\%) when using Real time PCR.

Conclusion: The results indicated a moderate incidence of occult HBV in renal transplant patients in Khartoum, Sudan. These results also indicated that occult HBV may not be detectable using conventional PCR but can be detected by using Real time PCR and Multiplex Nested PCR. Multiplex Nested PCR test can also detect Occult HBV at higher frequency by detecting viral genotypes which cannot otherwise be detected by using Real time PCR alone. This notion is very important to avoid accidental transmission through dialysis machines or blood transfusion.

Keywords: Renal transplant patients; HBV Genotypes; Occult HBV; HBsAg; Anti-HBc antibodies

\section{Introduction}

Human Hepatitis B Virus (HBV) infection is a significant health problem and is a principal factor in renal and liver disease. It is postulated that over five hundred million individuals are infected with $\mathrm{HBV}$ worldwide and more than one million deaths are annually attributed to the effects of HBV infection [1,2].

Nowadays, renal transplant patients experience less morbidity and mortality as result of infections than during the initial decades after the advent of renal transplantation. However, infections remain significant threats to the health of renal transplant recipient, mainly because infections are associated with organ rejection. Particularly important in this respect are the viruses which can play significant roles in morbidity and mortality in renal transplant recipient [3].

Occult Hepatitis B Virus Infection (OBI) infection can be defined as a particular form of $\mathrm{HBV}$ infection where patients are negative for
Hepatitis B Surface Antigen (HBsAg) but are anti-HBc antibodies positive, while at the same time being positive for HBV DNA in the liver and sometimes in the serum. OBI was first suspected in the 1970's when transmission of HBV infection through blood transfusion or in renal patients occurred from donors with serology suggestive of past HBV infection but with clearance of HBsAg [4,5]. OBI may be related to the host's immune response and/or the effect of co-infection with other disease agents [4]. Naturally occurring mutation in the promoter pre-S2/S region were detected in cases of OBI [6,7]. Later, it was observed that these mutations can cause modified HBsAg expression and an increased large-HBsAg/small-HBsAg ratio leading to reduced antigen secretion [8].

Several studies showed that different HBV genotypes are associated with different outcome e.g. HBV genotype D was connected with fulminant forms of hepatitis, while genotype B associated with liver cirrhosis [9-11]. 
This study aimed to determine the prevalence of occult HBV and HBV genotypes among renal transplant patients in Khartoum State, Sudan.

\section{Methods}

During the time frame of the present study (2015), 100 renal transplant patients were recruited from Dr. Salma and Ibin-Sina Hospital centers for transplantation and hemodialysis, Khartoum, Sudan, Blood samples were collected in EDTA container and centrifuged at $3000 \mathrm{rpm}$ for 5 minutes. Obtained plasma samples were then labeled and stored at $-20^{\circ} \mathrm{C}$ until further analyses.

\section{Serology}

Commercial ELISA kits including sandwich ELISA for HBsAg (Cut-off $=($ mean $\mathrm{NC} \times 2.1 ; \mathrm{OD}=450 \mathrm{~nm}$; positivity of $>1.0)$ and competitive ELISA for anti-HBc (Cut-off $=($ mean $\mathrm{NC} \times 0.5$; OD $=450$ $\mathrm{nm}$; positivity of $<1.0$ ) (Diagnostic Automation/Cortez Diagnostic Inc. USA) were used according to the procedures described by the manufacturers. All samples with negative $\mathrm{HBsAg}$ and positive results for $\mathrm{HBc}$ antibodies were further processed for DNA extraction.

\section{Polymerase Chain Reaction (PCR)}

DNA was extracted from patient's plasma materials using commercial Kit (Analytik Jena, Germany) according to manufacturer's instructions. Briefly, $200 \mu \mathrm{l}$ of lysis solution CBV/Carrier Mix into a 2.0 $\mathrm{ml}$ reaction was added to $200 \mu \mathrm{l}$ plasma sample and $20 \mu \mathrm{l}$ of proteinase $\mathrm{K}$, and then mix and incubated at $70^{\circ} \mathrm{C}$ for 10 minutes. Subsequently, $400 \mu \mathrm{l}$ of binding solution SBS was added to the sample after which all the lysis mix of the resulting solution was applied to a column. A volume of $500 \mu \mathrm{l}$ of washing solution HS and $650 \mu \mathrm{l}$ washing solution LS two time was added for washing and the nucleic acids were eluted with $60 \mu \mathrm{l}$ pre- heat RNase-free water and stored at $-20^{\circ} \mathrm{C}$ until used.

The PCR was performed by processing the extracted DNA from plasma with primers that are specific for the HBsAg gene of HBV. The primers used consisted of a forward primer

5'-TCGGAAATACACCTCCTTTCCATGG3' HBV genome (3531377) and reverse primer, 3'GCCTCAAGGTCGGTCGTTGACA-5' HBV genome (702-1681), optimized PCR reaction for HBV amplification was performed according to Mohammed AA, et al. [12]. $10 \mu \mathrm{l}$ of the amplified product was subjected to direct analysis by gel electrophoresis in $2 \%$ agarose. The product was visualized by using UV solo TS Gel documentation system, (Analytik Jena, Germany). The expected size of surface antigen gene amplicon was $350 \mathrm{bp}$.

\section{Multiplex Nested PCR}

A genotyping system based on a two-tube Multiplex Nested PCR method? Using type-specific primers was used in assigning Hepatitis $B$ genotypes A-F based on pre-S1 through S genes. The HBV primers S1-2 and P1 were universal outer primers. Primer B2 was used as the inner sense primer with a combination of other antisense primers for HBV genotypes A, B, and C in a multiplexing system named "Mix A". Primer B2R was used as the antisense inner primer with a combination of sense primers for HBV genotypes $\mathrm{D}, \mathrm{E}$ and $\mathrm{F}$ in a multiplexing system named "Mix B". The HBV genotype specific primers used have been designed based on the conserved nature of those sequences within a genotype and optimized for Multiplex Nested PCR reaction for HBV amplification according to [13,9]. The system of mix A and B have passed on only one program containing different parameters. The samples were visualized on a gel documentation System. The expected band size of a genotype of Mix A is Type A-68bp, type
B-281 bp and type C-122 bp and Mix B type D-119 bp, type E-167 bp, and type F-97 bp [9].

\section{Real time PCR}

The Real-time PCR was performed by using Hepatitis B Viral DNA Quantitative Fluorescence Diagnostic Kit (fast HBV, PCR-Fluorescence Probing) (Sansure-Biotech Inc. China) according to manufacturer's instructions. Briefly, $5 \mu \mathrm{l}$ of each plasma specimen, positive control, and negative control, quantitative reference A, B, C, D standards were transferred directly to a PCR reaction tube and thoroughly mixed it with $5 \mu \mathrm{l}$ DNA lysis buffer and then incubated for 10 minutes.

In another PCR tube PCR-master mix was prepared using $38 \mu \mathrm{l}$ of HBV PCR mix, $2 \mu \mathrm{l}$ of enzyme mix and $0.2 \mu$ internal controls. The lysat was then mixed with PCR master mix. The final volume was 50 $\mu \mathrm{l}$ for a single reaction. The thermal cycling conditions were 2 minutes at $50^{\circ} \mathrm{C}, 2$ minutes at $94^{\circ} \mathrm{C}$ for initial denaturation and 45 cycles of 15 seconds at $94^{\circ} \mathrm{C}$ for denaturation and 30 seconds at $57^{\circ} \mathrm{C}$ for annealing and extension and finally cooling for 10 seconds at $25^{\circ} \mathrm{C}$. The reaction was performed using Rotor-gene Q Real time PCR machine (Qiagen, Germany).

\section{Statistical analysis}

All data were statistically analyzed by statistical package of social science (IBM SPSS version 20.0) for windows software package. A probability $\leq 0.05$ was considered statistically significant result. Kappavaue was evaluated as follows, values $<0$ no agreement; $0-0.20$ slight; $0.21-0.40$ fair; $0.41-0.60$ moderate; $0.61-0.80$ substantial and 0.81-1 almost perfect agreement.

\section{Results}

\section{Detection of HBsAg and HBcAbs}

A total of 100 samples were tested for HBsAg, Ninety-seven samples (97\%) were negative for HBsAg by ELISA. The 97 samples (that were HBsAg negative) were then tested for anti-HBc using ELISA. Out of these, 60 samples $(61.9 \%)$ were negative for anti-HBc, while thirtyseven samples (38.1\%) samples tested positive for anti-HBc (Table 1). According to the gender, anti-HBc was detected in $23(62.2 \%)$ males and $14(37.8 \%)$ females (Table 1$)$.

\section{Detection of HBV DNA and HBV genotype}

A total of 37 samples that were negative for $\mathrm{HBsAg}$ and positive for anti-HBc were tested for HBV DNA using PCR, Real time PCR and for HBV genotypes using Multiplex Nested PCR. HBV DNA was detected in $0(0.0 \%)$ samples using PCR and in 19(51.4\%) samples using Real time PCR, while different HBV genotypes (A, D and E) either singly or mixedly were detected in 24(64.9\%) samples using Multiplex Nested PCR. According to gender, DNA was detected by Multiplex Nested PCR in $15(65.2 \%)$ males and 9(64.3\%) females, and by using Real time

Table 1: Frequency of Anti-HBc according to gender.

\begin{tabular}{|l|c|c|c|}
\hline \multirow{2}{*}{ Gender } & \multicolumn{2}{|c|}{ Anti-HBc } & \multirow{2}{*}{ Total } \\
\cline { 2 - 3 } & Positive & Negative & \\
\hline Male & $23(62.2 \%)(42 \%)^{*}$ & $32(53.3 \%)(58 \%)^{*}$ & $55(56.7 \%) 100 \%$ \\
\hline Female & $14(37.8 \%)(33 \%)^{* *}$ & $28(46.7 \%)(67 \%)^{* *}$ & $42(43.3 \%) 100 \%$ \\
\hline Total & $37(38.1 \%)^{* * *}$ & $60(61.9 \%)^{* * *}$ & $97(100 \%)$ \\
\hline
\end{tabular}

* \% out of total males; $* * \%$ out of total females; $* * * \%$ out of total HBsAg negative patents. 
PCR in 11(47.8\%) males and 8(57.1\%) females (Tables 2 and 3). The genotypes of HBV and their numbers detected using Multiplex Nested PCR were as follows; A-0(0\%), D-0(0\%), E-9(37.5\%), D/E-13(54.1\%), $\mathrm{A} / \mathrm{D}-1(4.2 \%)$ and $\mathrm{A} / \mathrm{D} / \mathrm{E}-1(4.2 \%)$. The frequency of Occult DNA was highest in the above 40 years old age group and no occult DNA was detected in the under 15 years old age group (Table 4) (Figures 1-3).

Using Multiplex Nested PCR the prevalence was not significantly higher (P.value $=0.47$ ) in males than female, like while, using Real time PCR the prevalence was not significantly higher (P.value $=1)$ in males than in females. When comparing Real time PCR and Multiplex Nested PCR, no significantly more females (P.value $=1$ ) were detected by Multiplex Nested PCR than Real time PCR, however significantly more males (P.value $=0.015$ ) were detected by Multiplex Nested PCR than Real time PCR. Kappa values for Real time PCR and Multiplex Nested PCR vs. PCR was 0.0 indicating no agreement, but fair agreement (Kappa value was 0.292) was found between Multiplex Nested PCR and Real time PCR (Tables 5 and 6).

\section{Discussion}

The present study was aimed to determine occult hepatitis B and hepatitis B genotypes among renal transplant patients in Khartoum, Sudan. Ninety-seven (97\%) of our study subjects were negative for HBsAg, of whom 37(38.1\%) were positive for HBc antibodies. Similar result were reported in Venezuela, India, and Iran by Gutierrez C, et al., Duseja A, et al., and Sofian M, et al. respectively [14-16], but these authors were not able to detect occult hepatitis B in their tested subjects. However, Mohammed AA, et al., [12] were able; using the same primers as ours; to detect occult HBV in 3(3.3\%) of haemodialysis patients in Khartoum State, Sudan. In the present study, we were able to detect OBI in $24.7 \%$ and $19.6 \%$ of renal transplant patients by using Multiplex Nested PCR and Real time PCR respectively.

The failure of PCR to detect occult HBV in our study population is unclear, but this may indicate a higher sensitivity of Multiplex Nested PCR and Real time PCR to detect occult hepatitis B infections. The occult HBV prevalence in the study as determined by Multiplex Nested PCR for genotypes (24.7\%) and Real time PCR (19.6\%) is similar to the prevalence in haemodialysis, renal transplant patients and other groups that ranges between 0 and $58 \%$ reported from different countries such as Germany, Italy, Brazil, Mexico [17-20].

Table 2: Frequency of Occult HBV in $\mathrm{HBc}$ positive patients using $\mathrm{PCR}$, Multiplex Nested PCR and Real time PCR according to gender.

\begin{tabular}{|c|c|c|c|c|}
\hline Gender & $\begin{array}{l}\text { Total } \\
\text { tested }\end{array}$ & PCR & Multiplex Nested(c)PCR & Real time $P C^{(d)}$ \\
\hline Male $^{(a)}$ & 23 & $0(0 \%)$ & $15(65.2 \%)$ & $11(47.8 \%)$ \\
\hline Female $^{(b)}$ & 14 & $0(0 \%)$ & $9(64.3 \%)$ & $8(57.1 \%)$ \\
\hline Total & 37 & $0(0 \%)$ & $24(64.9 \%)$ & $19(51.4 \%)$ \\
\hline
\end{tabular}

(a) Real time PCR-Multiplex Nested PCR $(P<0.05)$; (b) Real time PCRMultiplex Nested PCR $(p=0.015)$

(c) Multiplex Nested PCR ( $p=0.47) ;{ }^{(d)}$ Real time PCR $(P<0.05)$

Table 3: Overall frequency of Occult HBV using PCR, Multiplex Nested PCR and Real time PCR among 37 patients enrolled in the study.

\begin{tabular}{|l|c|c|c|}
\hline Samples/Test & PCR & Multiplex Nested PCR & Real time PCR \\
\hline Positive & O(0\%) & $24(64.9 \%)$ & $19(51.4 \%)$ \\
\hline Negative & $37(100 \%)$ & $13(35.1 \%)$ & $18(48.6 \%)$ \\
\hline Total & \multicolumn{3}{|c|}{$37(100 \%)$} \\
\hline
\end{tabular}

Table 4: Frequency of Occult HBV using PCR, Multiplex Nested PCR and Real time PCR according to age group.

\begin{tabular}{|l|c|c|c|c|}
\hline \multirow{2}{*}{$\begin{array}{c}\text { Age group } \\
\text { in years }\end{array}$} & \multicolumn{4}{|c|}{ Number of patients with HBV viruses (\%) } \\
\cline { 2 - 5 } & Total tested & PCR & Multiplex Nested PCR & Real time PCR \\
\hline$\leq \mathbf{1 5}$ & $6(16.2 \%)$ & $0(0 \%)$ & $0(0 \%)$ & $0(0 \%)$ \\
\hline $\mathbf{1 5 - 4 0}$ & $11(29.7 \%)$ & $0(0 \%)$ & $9(81.8 \%)$ & $7(63.3 \%)$ \\
\hline $\mathbf{4 0}$ & $20(54.1 \%)$ & $0(0 \%)$ & $15(75 \%)$ & $12(60 \%)$ \\
\hline Total & $37(100 \%)$ & $0(0 \%)$ & $24(64.9 \%)$ & $19(51.4 \%)$ \\
\hline
\end{tabular}

Table 5: Cross tabulation of Multiplex Nested PCR and Real Time PCR results vs. PCR results.

\begin{tabular}{|l|c|c|c|c|}
\hline \multirow{2}{*}{ PCR } & \multicolumn{2}{|c|}{ Multiplex Nested PCR } & \multicolumn{2}{c|}{ Real time PCR } \\
\cline { 2 - 5 } & Positive & Negative & Positive & Negative \\
\hline Positive & 0 & 24 & 0 & 19 \\
\hline Negative & 0 & 13 & 0 & 18 \\
\hline Total & 0 & 37 & 0 & 37 \\
\hline
\end{tabular}

(a),(b) Kappa value $=0.000$

Table 6: Cross tabulation of Real time PCR and Multiplex Nested PCR results.

\begin{tabular}{|l|l|c|c|c|}
\hline \multicolumn{2}{|c|}{ PCR } & \multicolumn{2}{c|}{ Real time PCR } & \multirow{2}{*}{ Total } \\
\cline { 3 - 4 } \multicolumn{2}{|c|}{} & Positive & Negative & \\
\hline $\begin{array}{l}\text { Multiplex } \\
\text { Nested PCR }\end{array}$ & Positive & 15 & 9 & 24 \\
\cline { 2 - 4 } & Negative & 4 & 9 & 13 \\
\hline Total & 19 & 18 & 37 \\
\hline
\end{tabular}

Kappa value $=0.292$

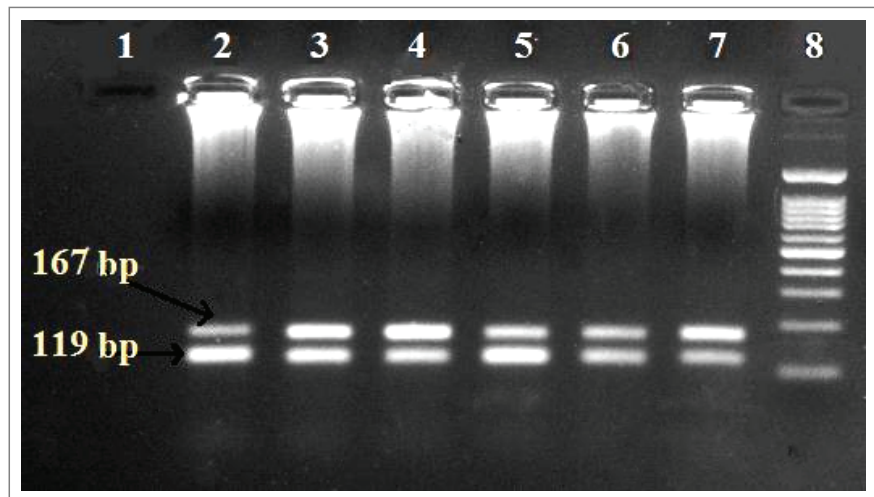

Figure 1: Agarose gel result for HBV genotypes using Multiplex nested PCR (lane 8: 100 bp ladder; lane 1: Negative control; lane 2, 3, 4, 5, 6, 7: Mixed genotypes D and E).

The high prevalence of OBI (51.4\%) using Real time PCR and 64.9\% using nested among $\mathrm{HBc}$ positive patients may be due to the fact that our patients were subjected to haemodialysis for various periods before kidney transplantation. This may have increased their risk of acquiring $\mathrm{HBV}$ and subsequently occult $\mathrm{HBV}$ infection.

The findings of the present study were higher than those reported by Peres AA, et al. [21], and by Bae E, et al. [22]; who found prevalences of $2 \%$ and $2.7 \%$, respectively. 

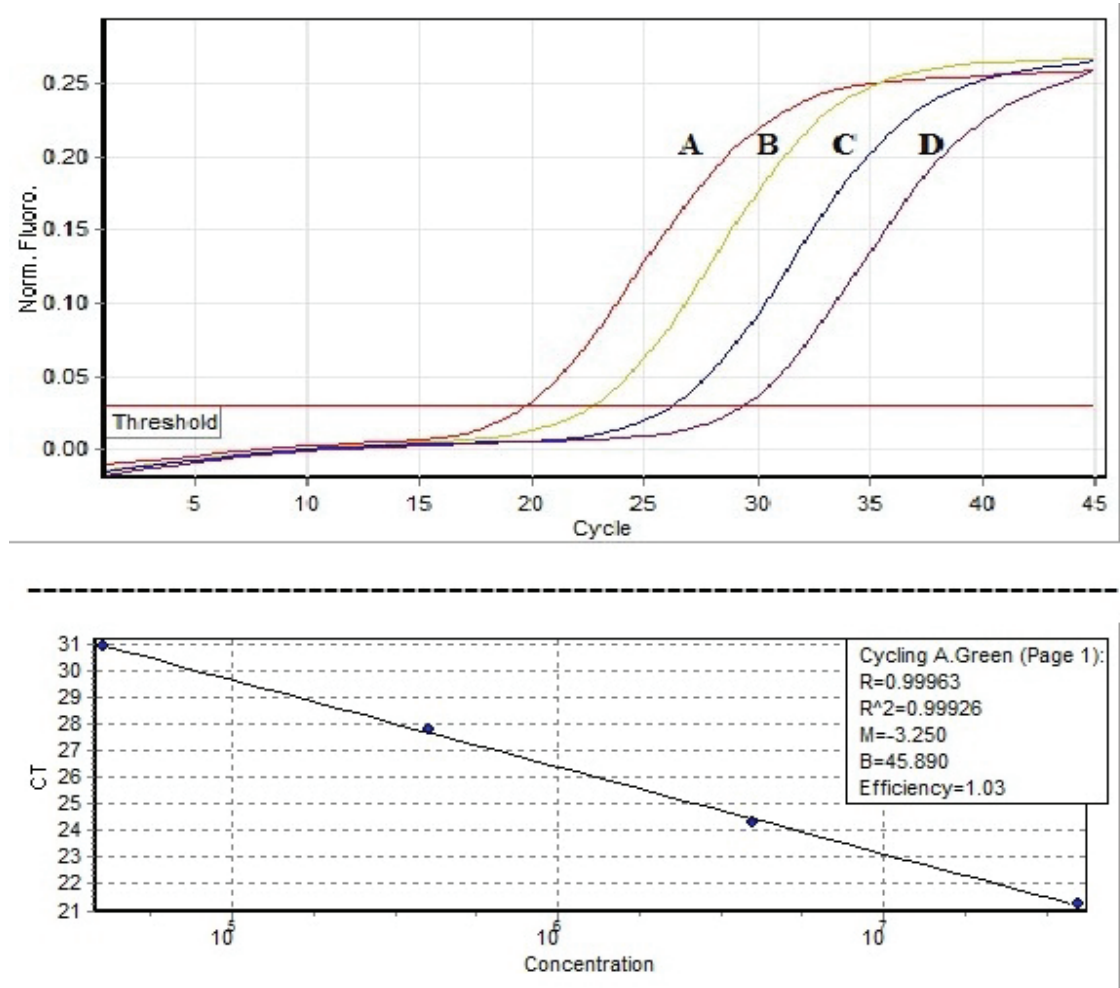

Figure 2: Graphic depiction of the linear range of quantitative references $A, B, C, D$ standard curve detection $\left(10^{4}, 10^{5}, 10^{6}, 10^{7} \mathrm{IU} / \mathrm{ml}\right)$ of Hepatitis B virus by Sansure kit, Fast HBV Real Time PCR assay.

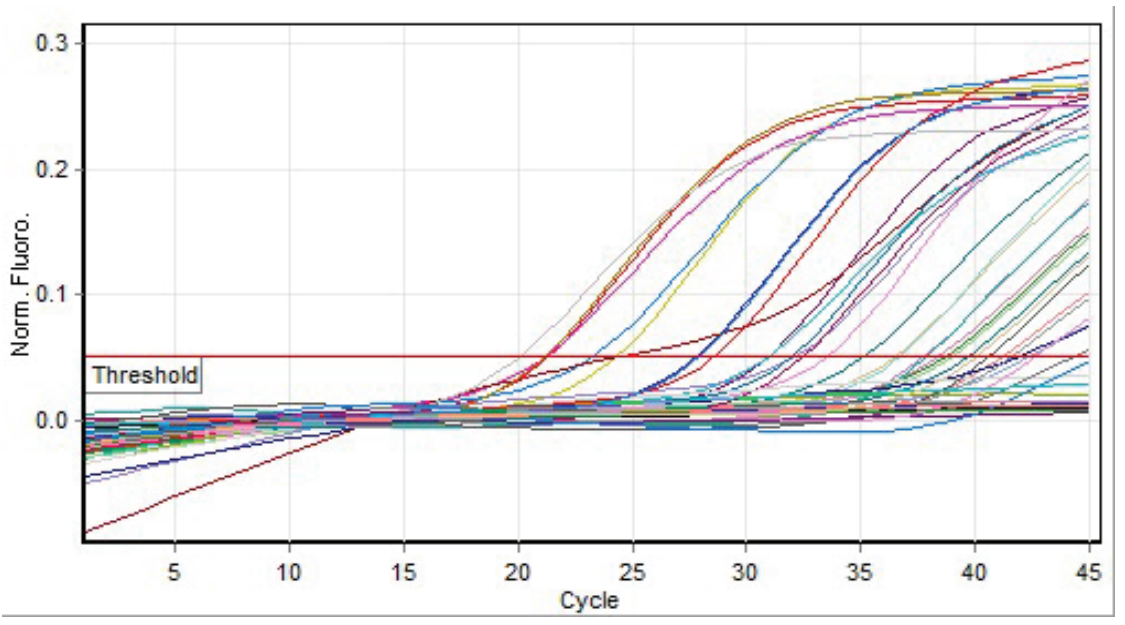

Figure 3: Graphic depiction of the linear range of positive control, negative control, quantitative references and positive samples, using Hepatitis B virus by Sansure kit, Hepatitis B Viral DNA Quantitative Fluorescence Diagnostic Kit.

There are no previous reports on the monitoring of occult HBV genotype using Multiplex Nested PCR among renal transplant patients where most of the studies were done using conventional PCR for Hepatitis B surface antigen gene or other hepatitis B genes, this may indicate that the conventional PCR methods for detecting OHB in renal transplant patients need to be reassessed.

In the present study, 3 different genotypes (A, D and E) were detected. Singular infections were only found with genotype $\mathrm{E}$ while mixed infections with 2 or 3 genotypes represented the majority of cases. This may be related to mutations, genetic variations or other causes. The genotypes E-9(37.5\%), D/E-13(54.1\%) were the dominant infections in our study which is in contrast to a study from Egypt by Maysaa ESZ, et al. [23] carried out in hemodialysis patients that reported genotypes $\mathrm{C}(44.4 \%), \mathrm{A}(27.8 \%)$ and $\mathrm{B}(22.2 \%)$ as the dominant genotypes.

Hepatitis B virus genotyping using Multiplex Nested PCR is simple, easy and cheaper than sequencing but sequencing and phylogenetic analysis based on nucleotide sequences produces the most accurate genotyping results. However, phylogenetic analysis is 
not an appropriate method for diagnostic testing in laboratories with limited resources and is more suitable for developing countries where advanced molecular testing is available. Real time PCR, on the other hand, could be more suitable method for testing for occult hepatitis B virus in developing countries but as indicated herein may miss some of the infections.

\section{Conclusion}

Occult HBV showed moderate prevalence in renal transplant patients in Khartoum State and can only be detected by using Multiplex Nested PCR and Real time PCR. In addition, our study may indicate that Occult HBV detection may require the use of more than one technique.

\section{Ethical Review}

The study was approved by the Ethical Review Committee (ERC) of Central Laboratory, Ministry of Higher Education and Scientific Research, Khartoum State, Sudan. Informed consents were obtained from adult patients or from parents or legal guardians of children.

\section{Consent for Publication}

Not applicable.

\section{Availability of Data and Material}

Data sharing not applicable to this article as no datasets were analyzed during the current study.

\section{Competing Interests}

Authors have no competing interests to declare.

\section{Funding Statement}

The Central Laboratory, Ministry of Higher Education and Scientific Research supported this work for Hepatitis viruses (2016HB10002-10, 2016HB10002-12).

\section{Acknowledgments}

We thank Ibin-Sina Hospital and Dr. Salma Center for transplantation and hemodialysis for allowing us to collect plasma samples from patients. This work was funded by the Central Laboratory, The Ministry of Higher Education and Scientific Research and Technology, Khartoum, Sudan.

\section{Author's Contributions}

MOM did the sample collection, ELISA, Multiplex Nested PCR, Real time PCR and drafted the manuscript. KME helped in the analysis of data and worked in the preparation and edition of the manuscript. IME contributed to the conception and design of the study and helped in the drafting of the manuscript. AME contributed to the conception and design of the study, the drafting of the manuscript. All authors read and approved the final manuscript.

\section{References}

1. Neuveut C, Wei Y, Buendia MA (2010) Mechanisms of HBV-related hepatocarcinogenesis. J Hepatol 52: 594-604.

2. Benhenda S, Cougot D, Buendia MA, Neuveut C (2009) Hepatitis B virus $X$ protein molecular functions and its role in virus life cycle and pathogenesis. Adv Cancer Res 103: 75-109.

3. Sia IG, Paya CV (1998) Infectious complications following renal transplantation. Surg Clin North Am 78: 95-112.

4. Fang Y, Shang QL, Liu JY, Li D, Xu WZ, et al. (2009) Prevalence of occult hepatitis $B$ infection among hepatopathology patients and healthy people in China. J Infect 58: 383-388.
5. Allain JP (2008) Occult hepatitis B virus infection: implications in transfusion. Vox Sang 86: 83-91.

6. Chaudhuri V, Tayal R, Nayak B, Acharya SK, Panda SK (2004) Occult hepatitis $B$ virus infection in chronic liver disease: full length genome and analysis of mutant surface promoter. Gastroenterology 127: 1356-1371.

7. Mu SC, Lin YM, Jow GM, Chen BF (2009) Occult hepatitis B virus infection in hepatitis B vaccinated children in Taiwan. J Hepatol 50: 264-272.

8. Sengupta S, Rehman S, Durgapal H, Acharya SK, Panda SK (2007) Role of surface promoter mutations in hepatitis $B$ surface antigen production and secretion in occult hepatitis B virus Infection. J Med Virol 79: 220-228.

9. Doumbia M, Kouassi BA, Kakou GS, Sevede D (2013) Molecular Characterization of Hepatitis B Virus Isolated from two Groups of Patients at Risk in Côte d'Ivoire. J Microbiol Res Rev 1: 61-66.

10. Lin CL, Kao JH (2015) Hepatitis B Virus Genotypes and Variants. Cold Spring Harb Perspect Med 5: a021436.

11. Shi YH (2012) Correlation between hepatitis B virus genotypes and clinical outcomes. Jpn J Infect Dis 65: 476-482.

12. Mohammed AA, Enan KA, Khair OS, Hussien MO, El Hussein ARM, et al. (2015) Prevalence of occult hepatitis B virus (HBV) infections in hemodialysis patients in Khartoum State, Sudan from 2012 to 2014. J Med Lab Diagn 6: 22-26.

13. Naito H, Havashi S, Abe K (2001) Rapid and specific genotyping system for hepatitis $B$ virus corresponding to six major genotypes by PCR using type specific primers. J Clin Microbiol 39: 362-364.

14. Gutierrez C, Leon G, Liprandi F, Pujol FH (2001) Low impact of silent hepatitis $B$ virus infection on the incidence of post-transfusion hepatitis in Venezuela. Rev Panam Salud Publica 10: 382-387.

15. Duseja A, Sharma S, Subramanian PG, Agnihotri SK, Chakraborti A, et al. (2003) Occult hepatitis B virus (HBV) infection in healthy blood donors. Indian J Pathol Microbiol 46: 690-692.

16. Sofian M, Aghakhani A, Izadi N, Banifazl M, Kalantar E, et al. (2010) Lack of occult hepatitis $B$ virus infection among blood donors with isolated hepatitis B core antibody living in an HBV low prevalence region of Iran. Int J Infect Dis 14: e308-e310.

17. Escobedo-Melendez G, Panduro A, Fierro NA, Roman S (2014) High prevalence of occult hepatitis $B$ virus genotype $\mathrm{H}$ infection among children with clinical hepatitis in west Mexico. Mem Inst Oswaldo Cruz 109: 728-737.

18. Hass M, Hannoun C, Kalinina T, Sommer G, Manegold C, et al. (2005) Functional analysis of hepatitis B virus reactivating in hepatitis B surface antigen-negative individuals. Hepatology 42: 93-103.

19. Sagnelli E, Imparato M, Coppola N, Pisapia R, Sagnelli $C$, et al. (2008) Diagnosis and clinical impact of occult hepatitis B infection in patients with biopsy proven chronic hepatitis $\mathrm{C}$ : a multicenter study. J Med Virol 80: 1547-1553.

20. Franz C, Perez Rde M, Zalis MG, Zalona AC, Rocha PT, et al. (2013) Prevalence of occult hepatitis $B$ virus infection in kidney transplant recipients. Mem Inst Oswaldo Cruz 108: 657-660.

21. Peres AA, Dias EA, Chesky M, Alvares-da-Silva MR, Jobim LF, et al. (2005) Occult hepatitis B in renal transplant patients. Transpl Infect Dis 7: 51-56.

22. Bae E, Park CH, Ki CS, Kim SJ, Huh W, et al. (2012) Prevalence and clinical significance of occult hepatitis $B$ virus infection among renal transplant recipients in Korea. Scand J Infect Dis 44: 788-792.

23. Maysaa ESZ, Douaa R, Ahmed E, Mostafa A (2014) Occult Hepatitis $B$ among Patients under Hemodialysis at Mansoura University Hospitals: Prevalence and Risk Factors. J Virol Antivir Res 3. 